\title{
Ion conducting and paramagnetic d-PCL(530)/siloxane-based biohybrids doped with $\mathrm{Mn}^{2+}$ ions
}

R.F.P. Pereira ${ }^{\mathrm{a}, \mathrm{b},{ }^{*}}$, J.P. Donoso ${ }^{\mathrm{c}}$, C.J. Magon ${ }^{\mathrm{c}}$, I.D.A. Silva ${ }^{\mathrm{c}}$, M.A. Cardoso ${ }^{\mathrm{b}}$, M.C.

Gonçalves $^{\text {b,d }}$, R.C. Sabadini ${ }^{\mathrm{e}}$, A. Pawlicka ${ }^{\mathrm{e}}$, V. de Zea Bermudez ${ }^{\mathrm{b}, \mathrm{d}}$ and M.M. Silva, ${ }^{\mathrm{a}}{ }^{*}$

${ }^{a}$ Chemistry Centre and Chemistry Department, University of Minho, 4710-057 Braga, Portugal

${ }^{\mathrm{b}}$ Chemistry Department, University of Trás-os-Montes e Alto Douro, 5000-801 Vila Real, Portugal

' IFSC, University of São Paulo, 13560-970 São Carlos, SP, Brazil

${ }^{\mathrm{d}}$ CQ-VR, University of Trás-os-Montes e Alto Douro, 5000-801 Vila Real, Portugal

${ }^{\mathrm{e}}$ IQSC, University of São Paulo, 13566-590 São Carlos, SP - Brazil

* Corresponding author

E-mail addresses: rpereira@quimica.uminho.pt (R.F.P. Pereira),nini@quimica.uminho.pt (M.M. Silva) 


\begin{abstract}
Amorphous $\alpha, \omega$-hidroxylpoly( $\varepsilon$-caprolactone) (PCL(530))/siloxane ormolytes doped with manganese perchlorate $\left(\mathrm{Mn}\left(\mathrm{ClO}_{4}\right)_{2}\right)\left(\mathrm{d}-\mathrm{PCL}(530) /\right.$ siloxane $\left._{\mathrm{n}} \mathrm{Mn}\left(\mathrm{ClO}_{4}\right)_{2}\right)$ with $\mathrm{n}=$ 20,50 , and 100), thermally stable up to at least $200{ }^{\circ} \mathrm{C}$, were synthesized by the sol-gel method. Ionic conductivity values up to $4.8 \times 10^{-8}$ and $2.0 \times 10^{-6} \mathrm{~S} \mathrm{~cm}^{-1}$ at about 25 and $100{ }^{\circ} \mathrm{C}$, respectively, where obtained for $\mathrm{n}=20$. FT-IR data demonstrated that the hydrogen bonding interactions present in the non-doped d-PCL(530)/siloxane host hybrid matrix were significantly influenced by the inclusion of $\mathrm{Mn}\left(\mathrm{ClO}_{4}\right)_{2}$ which promoted the formation of more oxyethylene/urethane and urethane/urethane aggregates. In addition, the $\mathrm{Mn}^{2+}$ ions bonded to all the "free" $\mathrm{C}=\mathrm{O}$ groups of the urethane cross-links and to some of the "free" ester groups of the amorphous PCL(530) chains. In the electrolytes, the $\mathrm{ClO}_{4}{ }^{-}$ions were found "free" and bonded to the $\mathrm{Mn}^{2+}$ ions along a bidentate configuration. The magnitude of the electron paramagnetic resonance $\left(\right.$ EPR) hyperfine constant of the analyzed samples $\left(A \approx 90 \times 10^{-4} \mathrm{~cm}^{-1}\right)$ suggested that the bonding between $\mathrm{Mn}^{2+}$ ions and the surrounding ligands is moderately ionic. The synthetized d-PCL(530)/siloxane ${ }_{n} \mathrm{Mn}\left(\mathrm{ClO}_{4}\right)_{2}$ biohybrids have potential application in paramagnetic, photoelectrochemical and electrochromic devices.
\end{abstract}

Keywords: poly(e-caprolactone)/siloxane biohybrids, manganese perchlorate, sol-gel, ionic conductivity, paramagnetism. 


\section{Introduction}

Polymer electrolytes (PEs) have attracted much interest to the scientific community because of their technological application in the domain of solid state electrochemistry, in particular for the fabrication of advanced batteries, sensors, photoelectrochemical, and electrochromic devices (ECDs) [1-3]. Actual research on solid-state electrochemistry seeks a compromise between "green" technologies, low cost, and highly efficient materials.

In the framework of the investigation of new "green" materials with improved properties and potential application as electrolytes in ECDs, several ormolyte (organically modified silicate electrolyte) systems composed of a sol-gel derived [4] poly( $\varepsilon$-caprolactone) (PCL(530), where 530 represents the average molecular weight in

$\mathrm{g} \mathrm{mol}^{-1}$ )-based di-urethanesil hybrid network (abbreviated as d-PCL(530)/siloxane) (Fig. 1) have been tested in the last few years. Doping of this organic-inorganic hybrid matrix with lithium [5-8], potassium [9], magnesium [10], europium [8], and erbium [6] salts, europium complexes [11] and ionic liquids [5] resulted in materials with attractive features, in particular high ionic conductivity and in the case of the lanthanidecontaining systems also high luminescence, and foreseen applications in eco-friendly ECDs. Prior to these works, applications of PCL and PCL-based hybrids had been proposed almost exclusively for the biomedical field, as biodegradable suture, artificial skin, resorbable prostheses, containers for sustained drug delivery, or bioactive coatings [12-20]. In fact PCL is a linear biopolymer that possesses interesting features, such as biocompatibility, permeability, hydrophobicity, biodegradability, non-toxicity for living organisms, and the ability of being resorbed after a certain period of implantation time. In the present work, the d-PCL(530)/siloxane biohybrid was doped with manganese perchlorate $\left(\mathrm{Mn}\left(\mathrm{ClO}_{4}\right)_{2}\right)$. The incorporation of $\mathrm{Mn}^{2+}$ ions has a two-fold interest, 
endowing the resulting hybrids with ionic conductivity and specially paramagnetic properties.

Indeed $\mathrm{Mn}^{2+}$ is a transition metal ion that has been extensively used as paramagnetic probe and as activator in various luminescent materials $[21,22] . \mathrm{Mn}^{2+}$-doped phosphors can be effectively excited by many sources, such as ultraviolet (UV), X-ray, and electric field [23-26] to yield emissions in the green, orange and red regions of the visible spectrum $[21,27,28]$. These emission properties motivated the wide use of $\mathrm{Mn}^{2+}$-based materials as phosphors for lamps and displays [25, 27, 29, 30]. Recently, Wang et al. [31] proposed the use of carbon-coated manganese silicate to act as anode material for lithium storage, exhibiting outstanding rate performances and high-rate cycling stability, and meeting the requirement for fast charging/discharging $\mathrm{Li}^{+}$batteries.

In this study, the structure, morphology, thermal features, ionic conductivity, and paramagnetic properties of the $\mathrm{Mn}\left(\mathrm{ClO}_{4}\right)_{2}$-doped d-PCL(530)/siloxane biohybrids are reported. The elucidation of the paramagnetic features has been performed by means of electron paramagnetic resonance spectroscopy (EPR), which is an effective and highly sensitive technique for the characterization of local order in a variety of solid-state systems [32-34]. EPR can provide valuable information about the oxidation state, ground state, and spin state of the paramagnetic ion. It enables the determination of the local symmetry of the ion environment, the nature of relevant spin interactions (e.g., Zeeman interaction, fine structure splitting, hyperfine coupling and exchange interaction) and the extent of covalency of the metal-ligand bond. EPR studies using $\mathrm{Mn}^{2+}$ ion as a probe have been very useful in the understanding of both the local coordination symmetry and magnetic properties of $\mathrm{Mn}^{2+}$ ions incorporated in a variety of materials, such as glasses [35-37], zeolites [38-40] and polymers [41]. 
We believe that the present investigation represents an important contribution towards the understanding of the interactions between the d-PCL(530)/siloxane systems and metal ions.

\section{Experimental}

\subsection{Materials}

Manganese (II) perchlorate $\left(\mathrm{Mn}\left(\mathrm{ClO}_{4}\right)_{2} \cdot x \mathrm{H}_{2} \mathrm{O}, 99 \%\right.$, Aldrich) was dried under vacuum at room temperature for several days prior to being used. $\alpha, \omega$-hidroxylpoly $(\varepsilon-$ caprolactone) $\left(\mathrm{PCL} \quad(530), \quad \mathrm{MW}=530 \mathrm{~g} \mathrm{~mol}^{-1}, \quad\right.$ Fluka $)$ and 3isocyanatepropyltriethoxysilane (ICPTES, 95\%, Aldrich) were used as received. Ethanol $\left(\mathrm{CH}_{3} \mathrm{CH}_{2} \mathrm{OH}, 99.9 \%\right.$, Merck) and tetrahydrofuran (THF, 99.9\%, Merck) were stored over molecular sieves. High-purity deionized water $\left(\mathrm{H}_{2} \mathrm{O}\right)$ was used in all experiments.

\subsection{Synthesis}

The $\mathrm{Mn}\left(\mathrm{ClO}_{4}\right)_{2}$-doped d-PCL(530)/siloxane-based biohybrids were prepared based on the procedure described in detail elsewhere [7]. The first stage of the synthesis involved the formation of a urethane cross-link between the hydroxyl $(-\mathrm{OH})$ end groups of the $\operatorname{PCL}(530)(0.8 \mathrm{~g}, 1.5 \mathrm{mmol})$ chains and the isocyanate $(-\mathrm{N}=\mathrm{C}=\mathrm{O})$ groups of ICPTES (745 $\mu \mathrm{L}, 3.0 \mathrm{mmol}$ ) to yield the organic-inorganic hybrid precursor. This reaction occurred in THF medium at $70-80{ }^{\circ} \mathrm{C}$ and in a sealed flask. The grafting process was infrared monitored during the formation of the urethane groups. The intensity of the strong and sharp band, characteristic of the stretching vibration of the $-\mathrm{N}=\mathrm{C}=\mathrm{O}$ group of ICPTES and typically located at $2273 \mathrm{~cm}^{-1}$ was progressively reduced until it 
disappeared upon completion of the reaction. In parallel, a series of new bands, associated with the vibrations of the urethane group, appeared in the $1800-1500 \mathrm{~cm}^{-1}$ spectral region. The d-PCL(530)/siloxane precursor was obtained as a yellowish transparent oil.

In the second stage of the synthesis procedure, a mixture of $\mathrm{CH}_{3} \mathrm{CH}_{2} \mathrm{OH}(705 \mu \mathrm{L}, 12.1$ mmol) and $\mathrm{H}_{2} \mathrm{O}(82 \mu \mathrm{L}, 4.6 \mathrm{mmol})$ was added to the d-PCL(530)/siloxane precursor obtained in the previous step to promote the hydrolysis and condensation reactions characteristic of the sol-gel process. The molar ratio ICPTES: $\mathrm{CH}_{3} \mathrm{CH}_{2} \mathrm{OH}: \mathrm{H}_{2} \mathrm{O}$ used was 1:4:1.5. An appropriate mass of $\mathrm{Mn}\left(\mathrm{ClO}_{4}\right)_{2}$ (Table 1) was incorporated immediately after the addition of $\mathrm{CH}_{3} \mathrm{CH}_{2} \mathrm{OH}$ and $\mathrm{H}_{2} \mathrm{O}$. The final mixture was stirred for $30 \mathrm{~min}$ and then cast into a Teflon mould, which was covered with Parafilm and left in a fume cupboard for $24 \mathrm{~h}$. Xerogel films were produced after aging for 1 month in an oven at $50{ }^{\circ} \mathrm{C}$ followed by drying under vacuum at $90{ }^{\circ} \mathrm{C}$ for 3 days prior to being analyzed.

The biohybrids prepared were produced as yellowish flexible xerogel films (Fig. 2) and were identified using the notation d-PCL(530)/siloxane ${ }_{n} \mathrm{Mn}\left(\mathrm{ClO}_{4}\right)_{2}$, where $\mathrm{n}$ (salt composition) indicates the number of $\left(-\mathrm{C}(=\mathrm{O})\left(\mathrm{CH}_{2}\right)_{5} \mathrm{O}-\right)$ PCL repeat units per $\mathrm{Mn}^{2+}$ ion. Samples with $n=100,50$ and 20 were prepared (Table 1).

Table 1. Composition of the d-PCL(530)/ siloxane $_{n} \mathrm{Mn}\left(\mathrm{ClO}_{4}\right)_{2}$ biohybrids.

\begin{tabular}{cccc}
\hline $\mathrm{n}$ & $\begin{array}{c}\mathrm{m}(\mathrm{PCL}(530)) \pm 0.01 \\
(\mathrm{mg})\end{array}$ & $\begin{array}{c}\mathrm{m}\left(\mathrm{Mn}\left(\mathrm{ClO}_{4}\right)_{2}\right) \pm 0.01 \\
(\mathrm{mg})\end{array}$ & $\begin{array}{c}\mathrm{n}^{\prime}\left(\mathrm{Mn}\left(\mathrm{ClO}_{4}\right)_{2}\right) \\
(\mathrm{mmol})\end{array}$ \\
\hline 100 & 803.83 & 14.25 & 0.056 \\
50 & 805.14 & 28.54 & 0.112 \\
20 & 806.72 & 71.48 & 0.282 \\
\hline
\end{tabular}

\subsection{Characterization}


The total ionic conductivity of the samples was determined by locating an electrolyte disk between two $10 \mathrm{~mm}$ diameter ion-blocking gold electrodes (Goodfellow, > $99.95 \%$ ) to form a symmetrical cell. The electrode/ormolyte/electrode assembly was secured in a suitable constant volume support and installed in a Büchi TO51 tube oven with a K-type thermocouple (precision of about $\pm 0.2^{\circ} \mathrm{C}$ ) placed close to the electrolyte disk to measure the sample temperature. Bulk conductivities of the electrolyte samples were obtained during heating cycles using the complex plane impedance technique with the Autolab PGSTAT-12 (Eco Chemie) equipment between room temperature $\left( \pm 20^{\circ} \mathrm{C}\right)$ and $100{ }^{\circ} \mathrm{C}$ and at approximately $10{ }^{\circ} \mathrm{C}$ intervals. The ionic conductivity was evaluated for frequencies between $500 \mathrm{mHz}$ and $65 \mathrm{kHz}$.

Differential scanning calorimetry (DSC) measurements were performed in a Mettler Toledo DSC 821e calorimeter. Prior to the analyses, the samples were dried in a desiccator containing phosphorous pentoxide $\left(\mathrm{P}_{2} \mathrm{O}_{5}\right)$ for 3 days. The DSC analyses were conducted over a temperature range of 0 to $300{ }^{\circ} \mathrm{C}$, at a heating rate of $10{ }^{\circ} \mathrm{C} \mathrm{min}^{-1}$, and under argon purge with $50 \mathrm{~mL} \mathrm{~min}^{-1}$ rate flow. All films were sealed in standard $40 \mu \mathrm{L}$ aluminum crucibles (Mettler Toledo).

Thermogravimetric analysis (TGA) were performed with a Shimadzu TGA-50 equipment. The measurements were conducted between 30 and $900{ }^{\circ} \mathrm{C}$, at a heating rate of $10{ }^{\circ} \mathrm{C} \mathrm{min}^{-1}$, and under a nitrogen atmosphere with $60 \mathrm{~mL} \mathrm{~min}{ }^{-1}$ rate flow. Before each analysis and aiming to eliminate the traces of solvent and/or absorbed water, all the samples were subject to a first run from 30 to $105^{\circ} \mathrm{C}$, at a heating rate of $20{ }^{\circ} \mathrm{C} \mathrm{min}-1$, followed by a second isothermal run at $105^{\circ} \mathrm{C}$ during 10 minutes.

Polarized optical microscopy (POM) images were recorded using an OPTIKA B600POL microscope equipped with a $8 \mathrm{Mpixel}$ digital Photo Camera. The images were analyzed using the OPTIKA Vision Pro software. 
$\mathrm{X}$-ray diffraction $(\mathrm{XRD})$ measurements were carried out at room temperature with $\mathrm{X}$ ray Rigaku Utma 4 diffractometer, power of $50 \mathrm{kV} / 50 \mathrm{~mA}$ and $\mathrm{Cu} \mathrm{K} \alpha$ irradiation, speed of $2{ }^{\circ} \mathrm{C} \mathrm{min}^{-1}$, in an angle range $(2 \theta)$ of 3 to $60^{\circ}$, at room temperature.

Attenuated total reflectance Fourier transform infrared (ATR/FT-IR) spectra were registered in a Thermo Scientific Nicolet iS50 FTIR spectrometer, coupled to an ATR accessory with a diamond crystal. The instrument is controlled by the Omnic software package (version 9.2.28) from Thermo Fisher Scientific Inc. The spectra were collected in the 4000-400 $\mathrm{cm}^{-1}$ range by averaging 64 scans at a resolution of $4 \mathrm{~cm}^{-1}$. To deconvolute complex band envelopes, the non-linear curve-fitting procedure offered by the PeakFit software [42] was employed. To automatically place hidden peaks, the Residuals procedure was used. This procedure initially places peaks by finding local maxima in a smoothed data stream. Hidden peaks are then optionally added where peaks in the residuals occur. The best fit of the experimental data was obtained using Gaussian shapes and by varying the frequency, bandwidth, and intensity of the bands. A linear baseline correction with a tolerance of $0.2 \%$ was employed. The standard errors of the curve-fitting procedure were $<0.03$.

$\mathrm{X}$-band continuous-wave electron paramagnetic resonance (CW-EPR) spectra were recorded at $50 \mathrm{~K}$ on a Bruker Elexsys E580 spectrometer operating at $9.478 \mathrm{GHz}$, equipped with a continuous flow liquid helium Oxford cryogenic system. Solid state powder EPR spectra were simulated by the function "pepper" of the software package EasySpin [43] implemented in MATLAB (MathWorks, Inc.).

\section{Results and Discussion}

\subsection{Thermal characterization}


The DSC thermograms of the d-PCL(530)/siloxane ${ }_{20} \mathrm{Mn}\left(\mathrm{ClO}_{4}\right)_{2}$ biohybrids (Fig. 3) confirm the entirely amorphous character of the doped samples indicating that the addition of the salt did not alter the disordered nature of the host hybrid matrix [7]. In the case of d-PCL(530)/siloxane ${ }_{20} \mathrm{Mn}\left(\mathrm{ClO}_{4}\right)_{2}$ and d-PCL(530)/ siloxane $_{50} \mathrm{Mn}\left(\mathrm{ClO}_{4}\right)_{2}$ a week broad endothermic peak is seen at ca. $98^{\circ} \mathrm{C}$ (onset at about $36{ }^{\circ} \mathrm{C}$ ) and at ca. $91{ }^{\circ} \mathrm{C}$ (onset at about $14{ }^{\circ} \mathrm{C}$ ), respectively. This endotherm probably corresponds to the loss of adsorbed solvent(s).

The DSC curve of the salt (Fig. 3) displays two endothermic peaks centred at ca. $50{ }^{\circ} \mathrm{C}$ ( $\mathrm{T}_{\text {onset }}$ at ca. $46^{\circ} \mathrm{C}$ ) and $155^{\circ} \mathrm{C}\left(\mathrm{T}_{\text {onset }}\right.$ at ca. $\left.145^{\circ} \mathrm{C}\right)$. While the former event corresponds to a phase transition, a phenomenon often encountered in perchlorate salts $[44,45]$, the latter endotherm is associated with $\mathrm{Mn}\left(\mathrm{ClO}_{4}\right)_{2}$ melting [46]. None of these two peaks is seen in the DSC curves of the doped d-PCL(530)/siloxane materials suggesting the complete dissociation of $\mathrm{Mn}\left(\mathrm{ClO}_{4}\right)_{2}$ in the d-PCL(530)/siloxane medium.

The thermal behavior of the d-PCL(530)/siloxane ${ }_{n} \mathrm{Mn}\left(\mathrm{ClO}_{4}\right)_{2}$ biohybrids was also evaluated by TGA. The TGA curves shown in Fig. 4 demonstrate that below $200{ }^{\circ} \mathrm{C}$ all the xerogel samples are thermally stable. The onset of thermal degradation of the d$\mathrm{PCL}(530) /$ siloxane $_{n} \mathrm{Mn}\left(\mathrm{ClO}_{4}\right)_{2}$ materials is lower than that reported for the non-doped d-PCL(530)/siloxane network (around $300{ }^{\circ} \mathrm{C}$ ) [9] indicating that the presence of this guest salt had a non-stabilizing influence on the host d-PCL(530)/siloxane framework under an inert atmosphere. However, this value is similar to that found earlier for dPCL(530)/siloxane-based ormolytes doped with a mixture of $\mathrm{LiCF}_{3} \mathrm{SO}_{3}$ and $\operatorname{Er}\left(\mathrm{CF}_{3} \mathrm{SO}_{3}\right)_{3}$ [6]. Between 200 and $300{ }^{\circ} \mathrm{C}$ all the samples suffered an abrupt weight loss. At $300{ }^{\circ} \mathrm{C}$ the d-PCL(530)/siloxane ${ }_{20} \mathrm{Mn}\left(\mathrm{ClO}_{4}\right)_{2}$ hybrid revealed a dramatic weight loss of about $25 \%$. Interestingly, this marked weight loss of this salt-rich sample is similar to that observed in the case of the $\mathrm{Mn}\left(\mathrm{ClO}_{4}\right)_{2}$ TGA curve. In the $300-500{ }^{\circ} \mathrm{C}$ temperature range the thermal decomposition of all the doped samples was a multistep 
process (Fig. S1). Between 500 and $900{ }^{\circ} \mathrm{C}$, a plateau was attained and no further thermal degradation occurred. At the maximum temperature analyzed about $20 \%$ of the xerogels with $\mathrm{n}=100,50$ and 20 still remained to be decomposed. In summary, the progressive incorporation of $\mathrm{Mn}\left(\mathrm{ClO}_{4}\right)_{2}$ into d-PCL(530)/siloxane had a gradual negative impact on the thermal stability of the host framework. However, the thermal decomposition onset value is considered adequate for solid-state electrochemical devices.

\subsection{XRD and POM analyses}

The XRD patterns of d-PCL(530)/siloxane ${ }_{n} \mathrm{Mn}\left(\mathrm{ClO}_{4}\right)_{2}$ biohybrids display a broad peak, Gaussian in shape and centered at ca. $21^{\circ}$ (Fig. 5a). This peak, which is associated with ordering of the siliceous domains [47] reveals that the incorporation of the manganese salt did not affect the amorphous character of the non-doped d-PCL(530)/siloxane matrix [7, 9]. The POM images of the biohybrids (Fig. 5b) demonstrate the isotropic character of the samples, corroborating the XRD and DSC.

\subsection{Ionic conductivity}

Ac Impedance spectroscopy was employed to evaluate the electrochemical properties of the biohybrids. The results are presented through Nyquist plots (imaginary impedance Z' versus real impedance Z') (Fig. 6) and a plot of the temperature dependence of the ionic conductivity (Fig. 7).

The ionic conductivity was measured during the heating cycles and determined by Eq. 1 ,

$$
\sigma=\frac{d}{A \times R_{b}}
$$


where $d$ is the thickness, $A$ is the electrochemical active area and $R_{b}$ is the bulk resistance obtained from the intercept of the imaginary impedance (minimum value of Z') with the slanted line in the real impedance (Z') through the Randles circuit [48]. The Nyquist plots of Fig. 6 illustrate the mobility of ions due to charge transfer and diffusion processes. Typically, the Nyquist plot is described by three distinct parts: a semicircle located at the high-frequency range that corresponds to the charge transfer process, a straight line for lower frequencies that is related to the diffusion process, and the transition between these phenomena [2, 3]. In the three cases reproduced in Fig. 6 the semi-circle at higher frequencies indicates that the salt facilitates the charge transfer process due to the increase of ionic conductivity with respect to the non-doped matrix [10]. The decrease of the semi-circles diameter also suggests that the ion diffusion ability is improved with salt content. Accordingly, the analysis of Fig. 7 allows inferring that the progressive addition of salt to d-PCL(530)/siloxane induced the enhancement of the ionic conductivity. The highest values were measured at $n=20\left(4.8 \times 10^{-8}\right.$ and $2.0 \times 10^{-6} \mathrm{~S} \mathrm{~cm}^{-1}$ at about 25 and $100{ }^{\circ} \mathrm{C}$, respectively).

The temperature dependence of the ionic conductivity of the hybrid samples, displayed in Fig. 7, appears to follows the vehicular model, i.e., Vogel-Tammann-Fulcher (VTF) type profile in the measured temperature range.

As the temperature increases, the polymer segments has acquired sufficient energy to push against the hydrostatic pressure imposed by its neighboring ions and thus polymer can expand easily to produce free volume. The free volume around the polymer chains determines the resulting conductivity, represented by the overall mobility of ions and the polymer. Therefore, as temperature increases, ions or polymer segments can move into the free volume [49]. The ionic conductivity values exhibited by the ormolytes prepared in this work indicate that they are suitable for application on photoelectrochemical and electrochromic devices [50, 51]. The levels of ionic 
conductivity are also of the same order of magnitude as those reported for analogous hybrids doped with potassium [9] and magnesium [10] triflates, and approximately one order of magnitude lower than those measured for analogues doped with lithium [7-10, $52,53]$ or copper $[7-10,52,53]$ salts.

\subsection{FT-IR analysis}

In the d-PCL(530)/siloxane hybrid medium the $\mathrm{Mn}^{2+}$ ions may coordinate to the available functional groups provided by the host hybrid framework (the ether $-\mathrm{C}-\mathrm{O}-\mathrm{C}-$ oxygen atoms and the ester $\mathrm{C}=\mathrm{O}$ oxygen atoms of the PCL chains, and the urethane $\mathrm{C}=\mathrm{O}$ oxygen atoms of the cross-links) or naturally to the counter-ions (i.e., the perchlorate ions) [54]. Given the minor amount of ether groups per PCL repeat unit, it is clear that the $\mathrm{C}=\mathrm{O}$ oxygen atoms will essentially the main responsible for $\mathrm{Mn}^{2+}$ coordination. Therefore, upon incorporation into the host hybrid, these cations will bound to "free" urethane/ester $\mathrm{C}=\mathrm{O}$ groups or to $\mathrm{C}=\mathrm{O}$ groups present in hydrogenbonded aggregates. In the latter case, the $\mathrm{Mn}^{2+}$ ions need to destroy hydrogen bonds of these aggregates, leading to their partial or complete destruction. To evaluate the influence of $\mathrm{Mn}^{2+}$ doping on the strength and extent of the hydrogen bonding interactions in the d-PCL(530)/siloxane matrix, we carried out an FT-IR spectroscopic analysis of the samples in the $1800-1600 \mathrm{~cm}^{-1}$ spectral interval, usually known as the amide I band. This band can be resolved into several individual components corresponding to different $\mathrm{C}=\mathrm{O}$ environments: from "free" $\mathrm{C}=\mathrm{O}$ groups (in the highfrequency range) to hydrogen-bonded aggregates of variable strength (in the mid-tolow-frequency range). 
The FT-IR spectrum of the non-doped d-PCL(530)/siloxane matrix exhibits four components situated at $1762,1736,1720$, and $1692 \mathrm{~cm}^{-1}$ [11]. Each of these bands are associated with different $\mathrm{C}=\mathrm{O}$ chemical environments: the $1762 \mathrm{~cm}^{-1}$ and $1736 \mathrm{~cm}^{-1}$ bands are attributed to "free" $\mathrm{C}=\mathrm{O}$ groups of the urethane cross-links (A1) and of the ester groups of amorphous PCL(530) chains (A2), respectively; the $1720 \mathrm{~cm}^{-1}$ band indicates the presence of oxyethylene/urethane hydrogen-bonded aggregates (B1); whereas the components around 1692 and $1670 \mathrm{~cm}^{-1}$ are assigned to the absorption of $\mathrm{C}=\mathrm{O}$ groups belonging to significantly more ordered hydrogen-bonded urethane/urethane $(\mathrm{C} 1)$ and ester/urethane (C2) aggregates [11, 55-57], respectively.

Fig. 8a shows the FT-IR spectra in the "amide I" region of $d$ PCL(530)/siloxane ${ }_{n} \mathrm{Mn}\left(\mathrm{ClO}_{4}\right)_{2}$ biohybrids. Although no significant differences are seen in the global spectral profile for $\mathrm{n}=100,50$, or 20 , the inclusion of $\mathrm{Mn}\left(\mathrm{ClO}_{4}\right)_{2}$ into d$\operatorname{PCL}(530) /$ siloxane led to changes in the environment of the $\mathrm{C}=\mathrm{O}$ groups which are revealed in the "amide I" region in terms of band reorganization. The incorporation of increasing quantities of the guest salt $(\mathrm{n}=100,50$ and 20) into the d-PCL(530)/siloxane host resulted in the complete saturation of the "free" $\mathrm{C}=\mathrm{O}$ groups from the urethane cross-links (A1) and in a considerable reduction of the amount of "free" ester groups of the amorphous PCL(530) chains (A2) (Fig. 8b). In parallel the fraction of oxyethylene/urethane and urethane/urethane hydrogen-bonded aggregates (B1 and C1, respectively) increased significantly. The concentration of ester/urethane aggregates (C2) did not suffer, however, major changes over the whole salt concentration range studied.

The inspection of the spectral signature of the $\mathrm{ClO}_{4}{ }^{-}$ion in the FT-IR spectra of the d$\operatorname{PCL}(530) /$ siloxane ${ }_{n} \mathrm{Mn}\left(\mathrm{ClO}_{4}\right)_{2}$ biohybrids allowed us gaining further insight into the local environment of the $\mathrm{Mn}^{2+}$ ions. This was made possible because the $\mathrm{ClO}_{4}{ }^{-}$ion is one of the most extensively employed ions probes in spectroscopic analyses aiming at 
elucidating ionic association [58]. As this ion has vibration modes that suffer characteristic changes (e.g., frequency shifts, splitting and/or intensity variations) upon coordination, it allows distinguishing the three main types of ionic species usually present in salt/polymer electrolytes: (a) high mobility "free" or weakly bonded ions; (b) low-mobility cations bonded strongly to the host polymer; (c) low-moderate mobility ionic aggregates (contact ion pairs and ionic multiplets).

The "free" $\mathrm{ClO}_{4}{ }^{-}$ion (tetrahedral symmetry $\left(\mathrm{T}_{\mathrm{d}}\right)$ ) has nine vibrational degrees of freedom distributed between four normal Raman active modes: v1 (A1) (infrared inactive), $v 2$ (E2) (infrared inactive), $v 3$ (T2), and $v 4$ (T2). These modes are expected at 931, 458, 1100 and $624 \mathrm{~cm}^{-1}$, respectively [59, 60]. Cation coordination lowers the $\mathrm{ClO}_{4}{ }^{-}$ion local symmetry leading to band splitting of degenerate vibrations and to activation of infrared-forbidden modes. The strength of ion association is manifested in the magnitude of band separation and of the frequency shift. Mono- or tridentate coordination of the oxygen atoms of $\mathrm{ClO}_{4}{ }^{-}$to a cation lowers the $\mathrm{T}_{\mathrm{d}}$ symmetry to $\mathrm{C}_{3 \mathrm{v}}$. As a consequence, the 3 -fold degenerate $v 3$ and $v 4$ vibrations split into two components (A1 and E), both in the infrared and Raman spectra. Bidentate coordination of the oxygen atoms of $\mathrm{ClO}_{4}{ }^{-}$to a cation lowers the $\mathrm{T}_{\mathrm{d}}$ symmetry to $\mathrm{C}_{2 \mathrm{v}}$. The splitting of the 2fold degenerate $v 2$ vibration into two bands (A1 and A2) in the Raman spectrum and the splitting of the 3 -fold degenerate $v 3$ and $v 4$ vibrations into three components (A1, B1, and B2) in the infrared and Raman spectra result.

In the present work we examined the $v 4 \mathrm{ClO}_{4}$ region of the FT-IR spectra of the dPCL(530)/siloxane ${ }_{n} \mathrm{Mn}\left(\mathrm{ClO}_{4}\right)_{2}$ biohybrids samples (Fig. 9(a)). The results of the curvefitting performed (Fig. 9(b) and Table 2) reveal that in the three samples studied the $\mathrm{ClO}_{4}{ }^{-}$ions were either "free" or bonded to the $\mathrm{Mn}^{2+}$ ions along a bidentate configuration. The marked growth of the integral area fraction of the $632 \mathrm{~cm}^{-1}$ component (Fig. 9(c)) resulting from the incorporation of increasing amounts of 
$\mathrm{Mn}\left(\mathrm{ClO}_{4}\right)_{2}$ to the host hybrid matrix indicates that the proportion of bidentate $\mathrm{ClO}_{4}{ }^{-}$ ions increased. A major reduction in the fraction of "free" ions occurred concomitantly, as demonstrated by the dramatic decrease of the integral area fraction of the $625 \mathrm{~cm}^{-1}$ component.

Table 2. Composition dependence of the integral area fraction (\%) of the resolved components $\left(\mathrm{cm}^{-1}\right)$ of the d-PCL(530)/siloxane ${ }_{n} \mathrm{Mn}\left(\mathrm{ClO}_{4}\right)_{2}$ biohybrids in the FT-IR $v_{4} \mathrm{ClO}_{4}$ region.

\begin{tabular}{|c|c|c|c|c|c|c|}
\hline \multicolumn{6}{|c|}{$\mathrm{n}$} & \multirow[b]{3}{*}{ Attribution $[58,59]$} \\
\hline \multicolumn{2}{|c|}{100} & \multicolumn{2}{|c|}{50} & \multicolumn{2}{|c|}{20} & \\
\hline$v$ & Area & $v$ & Area & $v$ & Area & \\
\hline 632 & 8.8 & 633 & 3.5 & 634 & 3.4 & Bidentate $\mathrm{ClO}_{4}^{-}$ \\
\hline 628 & 19.4 & 629 & 16.5 & 630 & 8.3 & Isotopic ${ }^{37} \mathrm{ClO}_{4}^{-}$ \\
\hline 625 & 35.1 & 625 & 30.9 & 626 & 20.4 & "Free" and bidentate \\
\hline & & & & & & $\mathrm{ClO}_{4}^{-}$ \\
\hline 621 & 28.8 & 622 & 40.2 & 622 & 44.2 & Bidentate $\mathrm{ClO}_{4}^{-}$ \\
\hline 618 & 7.9 & 618 & 8.9 & 617 & 18.9 & Isotopic ${ }^{37} \mathrm{ClO}_{4}^{-}$ \\
\hline - & - & - & - & 612 & 4.7 & non-assigned \\
\hline
\end{tabular}

\subsection{Electron Paramagnetic Resonance (EPR)}

Fig. 10 shows the $\mathrm{X}$-band $\mathrm{CW}$-EPR spectrum measured at $50 \mathrm{~K}$ of the $\mathrm{d}$ PCL(530)/siloxane ${ }_{n} \mathrm{Mn}\left(\mathrm{ClO}_{4}\right)_{2}$ biohybrids with increasing salt concentration of. In all the EPR spectra the signal consisted of a sextet with effective $g$-value $g \approx 2.0$ (centered at around $3300 \mathrm{G})$. The $\mathrm{Mn}^{2+}$ ion has a $3 \mathrm{~d}^{5}$ electronic configuration, a spin $S=5 / 2$, and 
ground state ${ }^{6} \mathrm{~S}_{5 / 2}$. The lowest orbital level of the free ion is a singlet, which is six-fold degenerate in spin. An axial or tetragonal distortion of the octahedral crystal field splits this singlet into three Kramer's doublets: $\pm 5 / 2, \pm 3 / 2$, and $\pm 1 / 2[32,33]$. The application of a magnetic field lifts the spin degeneracy of the Kramers' doublets, and as a consequence the resonances observed in the EPR spectra are due to transitions within the Kramers's doublets. The resonance at $g \approx 2.0$ is associated with $\mathrm{Mn}^{2+}$ ions in an environment close to octahedral symmetry and is believed to arise from transition within the $\pm 1 / 2$ Kramer doublet [61-64].

Mn has a stable isotope with non-zero nuclear spin $\left({ }^{55} \mathrm{Mn}\right)$ with $I=5 / 2(100 \%$ natural abundance). The EPR spectra of the $\mathrm{Mn}^{2+}$ ions at low $\mathrm{Mn}^{2+}$ concentration is further split into six lines by the hyperfine structure resulting from the dipole-dipole interaction between the magnetic moment of the ${ }^{55} \mathrm{Mn}$ nuclei and the electronic moment of the paramagnetic $\mathrm{Mn}^{2+}$ ion. The resonance at $\mathrm{g} \approx 2.0$ is due to allowed $\mathrm{M}_{\mathrm{s}}=1 / 2 \leftrightarrow-1 / 2$ magnetic dipolar transitions (selection rules $\Delta M_{\mathrm{S}}= \pm 1$ and $\Delta m_{\mathrm{I}}=0$, where $\mathrm{M}_{\mathrm{s}}$ and $m_{\mathrm{I}}$ are the electronic and nuclear spin state, respectively) from the ${ }^{6} \mathrm{~S}_{5 / 2}$ ground state of $\mathrm{Mn}^{2+}$

The spectra of Fig. 10 are similar to those reported for disordered materials, such as glasses and polymers. The weak features between the spin-allowed hyperfine lines of the resonance signal were attributed to spin "forbidden" transitions $\left(\Delta M \mathrm{~s}= \pm 1, \Delta m_{\mathrm{I}}= \pm\right.$ 1) $[65-67]$.

The EPR spectrum of the $\mathrm{Mn}^{2+}$ ions in the d-PCL(530)/siloxane host can be qualitatively understood in terms of the spin-Hamiltonian for $\mathrm{d}^{5}$ ions in axial symmetry [68]:

$$
\mathrm{H}=g \beta H \cdot S+D\left[S_{Z}^{2}-\frac{1}{3} S(S+1)\right]+A S \cdot I
$$


where $\beta$ is the Bohr magneton, $H$ is the applied magnetic field, $S$ is the spin component along the symmetry axis $z, A$ is the hyperfine coupling constant, and the other symbols have their usual meaning. The first term in the Hamiltonian represents the interaction of the $S=5 / 2$ electron spin with the external magnetic field $H$, i.e., the electron Zeeman interaction. For simplicity, the isotropic $g$-value was considered. The second term is the zero-field splitting (ZFS) Hamiltonian and is characterized by the axial crystal field parameter $D$. The third term is the hyperfine interaction describing the interaction between the $S=5 / 2$ electron spin with the $I=5 / 2$ nuclear spin of the ${ }^{55} \mathrm{Mn}$ isotope.

The experimental $\mathrm{Mn}^{2+}$ EPR spectra were analyzed by numerical simulation of the spin Hamiltonian (Eq. 2). Satisfactory fits to the experimental EPR spectra were obtained assuming two different $\mathrm{Mn}^{2+}$ species characterized by different coordination symmetries. The fit parameters for the species I included the $g$-value, $A$, and $D$. A strain parameter (specified by $D$-strain was also introduced to account for the heterogeneity of the environments around the paramagnetic center, which results in broad distributions of the principal values of the D-tensor [43]. The Hamiltonian parameter $D=612-661$ MHz (204 - $\left.220 \times 10^{-4} \mathrm{~cm}^{-1}\right)$ deduced from the simulated spectra (Table 3) suggests that the $\mathrm{Mn}^{2+}$ ions of species I are complexed by the d-PCL(530)/siloxane matrix in an axially distorted coordination symmetry. The fit parameters for the species II included only $g$ and $A$ (i.e., $D=0 \mathrm{MHz}$ ). A strain parameter (noted as $A$ strain) was used in samples with lower $\mathrm{Mn}^{2+}$ concentration $(\mathrm{n}=50$ and 100) to account for the distribution of $A$ values. For simplicity, $\mathrm{S}=1 / 2$ for the simulations of species II was assumed. The Hamiltonian parameters obtained for species II suggests that these $\mathrm{Mn}^{2+}$ ions are not coordinated to the matrix. The simulated spectra, shown in Fig. 10, were obtained by adding the contribution from species I and II with the Hamiltonian parameters given in Table 3. The agreement between the observed and the calculated spectra are 
satisfactory, since the simulated spectra closely reproduce the position and the intensities of the most prominent features.

Table 3. Summary of the spin Hamiltonian parameters of d$\operatorname{PCL}(530) /$ siloxane $_{n} \mathrm{Mn}\left(\mathrm{ClO}_{4}\right)_{2}$ biohybrids obtained from the simulation of the experimental EPR spectra measured at $50 \mathrm{~K}$. Lwpp refers to the peak-to-peak line width for isotropic broadening used for convolution of the CW-EPR spectrum. The first and second elements are the Gaussian and Lorentzian contributions, respectively. It should be noted that the $A$ and $D$ values are given in MHz units usually used in EPR simulation packages (conversion factor is $\left.1\left[\mathrm{~cm}^{-1}\right]=0.33356 \times 10^{-4}[\mathrm{MHz}]\right)$.

\begin{tabular}{|c|c|c|c|c|}
\hline Species & & $n=100$ & $n=50$ & $n=20$ \\
\hline I & Spin & $5 / 2$ & $5 / 2$ & $5 / 2$ \\
\hline & $g$ & 1.999 & 2.000 & 2.000 \\
\hline & $1 w p p(\mathrm{mT})$ & 1.41 .1 & 2.40 .67 & 1.52 .3 \\
\hline & $A(\mathrm{MHz})$ & 272 & 272 & 272 \\
\hline & $D(\mathrm{MHz})$ & 631 & 618 & 579 \\
\hline & $D$ strain $(\mathrm{MHz})$ & 656 & 661 & 612 \\
\hline II & Spin & $1 / 2$ & $1 / 2$ & $1 / 2$ \\
\hline & $g$ & 2.002 & 2.001 & 2.001 \\
\hline & 1 wpp $(\mathrm{mT})$ & 1.70 .0 & 1.80 .0 & 2.00 .37 \\
\hline & $A(\mathrm{MHz})$ & 268 & 269 & 269 \\
\hline & $A$ strain $(\mathrm{MHz})$ & 15 & 20 & - \\
\hline I : $\mathbf{I I}$ & Absorption & $253: 1$ & $261: 1$ & $447: 1$ \\
& integral & & & 9.474488 \\
\hline & Frequency $(\mathrm{GHz})$ & 9.475411 & 9.47674 & 9.4748 \\
\hline
\end{tabular}

The value of the hyperfine constant has been correlated with the nature of the bonding character between the $\mathrm{Mn}^{2+}$ ions and its ligands in the hybrid electrolytes. The correlation, which is mainly determined by the electronegativity of the $\mathrm{Mn}^{2+}$ neighbors, was ascertained by Van Wieringen $[69,70]$. In covalent semiconductors like Mn-Te, $A$ values are as low as $59 \times 10^{-4} \mathrm{~cm}^{-1}$, while in fluorite crystals, where the bonding is ionic, $A \approx 97 \times 10^{-4} \mathrm{~cm}^{-1}[35,71]$. The magnitude of the hyperfine constant derived for the 
samples in the present work $\left(A \approx 90 \times 10^{-4} \mathrm{~cm}^{-1}\right.$, Table 2$)$, suggests that the bonding between $\mathrm{Mn}^{2+}$ ions and the surrounding ligands is moderately ionic. This result is consistent with our previously reported study in $\mathrm{Cu}^{2+}$-doped d-PCL(530)/siloxane-based electrolytes, where the molecular bonding coefficients $\alpha^{2}$ and $\beta^{2}$ obtained by correlating the $\mathrm{Cu}^{2+}$ EPR spin Hamiltonian parameters and the optical absorption data suggested that bonding between the $\mathrm{Cu}^{2+}$ and its ligands was also moderately ionic [53]. These conclusions are in perfect agreement with the FT-IR data reported in the previous section in which solid spectral evidences were found pointing out strong interaction between the $\mathrm{Mn}^{2+}$ ions and the $\mathrm{C}=\mathrm{O}$ groups of the urethane cross-links and of the ester groups of the $\mathrm{PCL}(530)$ chains and also between the $\mathrm{Mn}^{2+}$ ions and the $\mathrm{ClO}_{4}{ }^{-}$ions. These two different cation environments could correspond to species I and II identified by EPR, respectively.

\section{Conclusions}

Paramagnetic amorphous d-PCL(530)/siloxane-based biohybrids doped with $\mathrm{Mn}\left(\mathrm{ClO}_{4}\right)_{2}$ were synthesized by sol-gel method. The incorporation of $\mathrm{Mn}^{2+}$ ions had a two-fold interest, endowing the resulting hybrids with ionic conductivity and paramagnetic properties. The ionic conductivity increased with salt concentration. The highest values were obtained for $\mathrm{n}=20\left(4.8 \times 10^{-8}\right.$ and $2.0 \times 10^{-6} \mathrm{~S} \mathrm{~cm}^{-1}$ at about 25 and $100{ }^{\circ} \mathrm{C}$, respectively).

The hydrogen bonding interactions present in the d-PCL(530)/siloxane matrix were influenced by the inclusion of $\mathrm{Mn}\left(\mathrm{ClO}_{4}\right)_{2}$, which promoted the formation of more oxyethylene/urethane and urethane/urethane aggregates. In the samples the $\mathrm{Mn}^{2+}$ ions interact with the "free" urethane and ester $\mathrm{C}=\mathrm{O}$ groups of the host hybrid matrix host 
and also with the $\mathrm{ClO}_{4}{ }^{-}$ions along a bidentate configuration. "Free" $\mathrm{ClO}_{4}{ }^{-}$ions were also detected, although their concentration decreased, as expected, with salt content.

The magnitude of the EPR hyperfine constant of the analyzed samples $\left(A \approx 90 \times 10^{-4}\right.$ $\mathrm{cm}^{-1}$ ) is in agreement with the FT-IR data suggesting that the bonding between $\mathrm{Mn}^{2+}$ ions and the surrounding ligands is moderately ionic. The $\mathrm{Mn}^{2+}$ ions identified as species I are coordinated to the d-PCL(530)/siloxane matrix along an axially distorted coordination symmetry, whereas the $\mathrm{Mn}^{2+}$ bounded to $\mathrm{ClO}_{4}{ }^{-}$ions are classed as species II.

The ionic conducting, combined with the thermal stability up to at least $200{ }^{\circ} \mathrm{C}$ and the paramagnetic properties, open interesting prospects for the potential application of the d-PCL(530)/siloxane ${ }_{n} \mathrm{Mn}\left(\mathrm{ClO}_{4}\right)_{2}$ biohybrids in paramagnetic, photoelectrochemical and electrochromic devices.

\section{Acknowledgements}

This work was supported by Fundação para a Ciência e a Tecnologia (FCT) and Feder (contracts PTDC/CTM-BPC/112774/2009, PEst-OE/QUI/UI0616/2014 and PEstC/QUI/UI0686/2013) and COST Action MP1202 "Rational design of hybrid organicinorganic interfaces". R.F.P.P. acknowledges FCT for a grant (SFRH/BPD/87759/2012). M.M.S. acknowledges CNPq (PVE grant 406617/2013-9), for a mobility grant. The financial support of the Brazilian agencies Capes and CNPq are gratefully acknowledged. Research was partially financed by the CeRTEV, Center for Research, Technology and Education in Vitreous Materials, FAPESP 2013/07793-6. 


\section{References}

[1] F.M. Gray, Polymer electrolytes, Royal Society of Chemistry, Cambridge, 1997.

[2] B.-Y. Chang, S.-M. Park, Electrochemical Impedance Spectroscopy, Annu. Rev. Anal. Chem., 3 (2010) 207-229.

[3] M. Park, X. Zhang, M. Chung, G.B. Less, A.M. Sastry, A review of conduction phenomena in Li-ion batteries, J. Power Sources, 195 (2010) 7904-7929.

[4] C.J. Brinker, G.W. Scherer, The physics and chemistry of sol-gel processing, Academic Press, San Diego, 1990.

[5] M. Fernandes, R. Leones, A.M.S. Costa, M.M. Silva, S. Pereira, J.F. Mano, E. Fortunato, R. Rego, V. de Zea Bermudez, Electrochromic devices incorporating biohybrid electrolytes doped with a lithium salt, an ionic liquid or a mixture of both, Electrochim. Acta, 161 (2015) 226-235. [6] M. Fernandes, V.T. Freitas, S. Pereira, E. Fortunato, R.A.S. Ferreira, L.D. Carlos, R. Rego, V.D. Bermudez, Green $\mathrm{Li}^{+}$- and $\mathrm{Er}^{3+}$-doped poly(epsilon-caprolactone)/siloxane biohybrid electrolytes for smart electrochromic windows, Sol. Energ. Mat. Sol. Cells, 123 (2014) 203-210. [7] S.C. Nunes, V. de Zea Bermudez, M.M. Silva, M.J. Smith, E. Morales, L.D. Carlos, R.A. Sá Ferreira, J. Rocha, Sol-gel derived Li+-doped poly( $\varepsilon$-caprolactone)/siloxane biohybrid electrolytes, J. Solid State Electrochem., 10 (2006) 203-210.

[8] M. Fernandes, S.S. Nobre, L.C. Rodrigues, A. Gonçalves, R. Rego, M.C. Oliveira, R.A.S. Ferreira, E. Fortunato, M.M. Silva, L.D. Carlos, V.d.Z. Bermudez, $\mathrm{Li}^{+}-$and $\mathrm{Eu}^{3+}$-doped poly $(\varepsilon-$ caprolactone)/siloxane biohybrid electrolytes for electrochromic devices, ACS Appl. Mater. Interfaces, 3 (2011) 2953-2965.

[9] M. Fernandes, L.C. Rodrigues, R.A.S. Ferreira, A. Gonçalves, E. Fortunato, M.M. Silva, M.J. Smith, L.D. Carlos, V. de Zea Bermudez, $\mathrm{K}^{+}$-doped poly(E-caprolactone)/siloxane biohybrid electrolytes for electrochromic devices, Solid State Ion., 204-205 (2011) 129-139. [10] J.C.S. Teixeira, M. Fernandes, V. de Zea Bermudez, P.C. Barbosa, L.C. Rodrigues, M.M. Silva, M.J. Smith, $\mathrm{Mg}^{2+}$-doped poly( $\varepsilon$-caprolactone)/siloxane biohybrids, Electrochim. Acta, 55 (2010) 1328-1332.

[11] M. Fernandes, V. de Zea Bermudez, R.A. Sá Ferreira, L.D. Carlos, A. Charas, J. Morgado, M.M. Silva, M.J. Smith, Highly photostable luminescent poly( $\varepsilon$-caprolactone)siloxane biohybrids doped with europium complexes, Chem. Mat., 19 (2007) 3892-3901.

[12] M. Prabaharan, M.A. Rodriguez-Perez, J.A. de Saja, J.F. Mano, Preparation and characterization of poly(L-lactic acid)-chitosan hybrid scaffolds with drug release capability, J. Biomed. Mater. Res. Part B Appl. Biomater., 81B (2007) 427-434.

[13] A. Kopytynska-Kasperczyk, P. Dobrzynski, M. Pastusiak, B. Jarzabek, W. Prochwicz, Local delivery system of doxycycline hyclate based on $\epsilon$-caprolactone copolymers for periodontitis treatment, Int. J. Pharm., 491 (2015) 335-344.

[14] A.G.A. Coombes, S.C. Rizzi, M. Williamson, J.E. Barralet, S. Downes, W.A. Wallace, Precipitation casting of polycaprolactone for applications in tissue engineering and drug delivery, Biomaterials, 25 (2004) 315-325.

[15] H.A. Declercq, T. Desmet, E.E.M. Berneel, P. Dubruel, M.J. Cornelissen, Synergistic effect of surface modification and scaffold design of bioplotted 3-D poly- $\varepsilon$-caprolactone scaffolds in osteogenic tissue engineering, Acta Biomater., 9 (2013) 7699-7708.

[16] L. Elomaa, S. Teixeira, R. Hakala, H. Korhonen, D.W. Grijpma, J.V. Seppälä, Preparation of poly( $\varepsilon$-caprolactone)-based tissue engineering scaffolds by stereolithography, Acta Biomater., 7 (2011) 3850-3856.

[17] T.R. Olsen, L.L. Davis, S.E. Nicolau, C.C. Duncan, D.C. Whitehead, B.A. Van Horn, F. Alexis, Non-invasive deep tissue imaging of iodine modified poly(caprolactone-co-1-4-oxepan1,5-dione) using X-ray, Acta Biomater., 20 (2015) 94-103.

[18] S.-H. Teng, P. Wang, J.-Q. Dong, Bioactive hybrid coatings of poly( $\varepsilon$-caprolactone)-silica xerogel on titanium for biomedical applications, Mater. Lett., 129 (2014) 209-212.

[19] Y. Niu, K.C. Chen, T. He, W. Yu, S. Huang, K. Xu, Scaffolds from block polyurethanes based on poly( $\varepsilon$-caprolactone) (PCL) and poly(ethylene glycol) (PEG) for peripheral nerve regeneration, Biomaterials, 35 (2014) 4266-4277. 
[20] V. Mkhabela, S.S. Ray, Biodegradation and bioresorption of poly( $\varepsilon$-caprolactone) nanocomposite scaffolds, Int. J. Biol. Macromol., 79 (2015) 186-192.

[21] T. Takeda, R.-J. Xie, N. Hirosaki, Y. Matsushita, T. Honma, Manganese valence and coordination structure in Mn,Mg-codoped $\gamma$-AlON green phosphor, J. Solid State Chem., 194 (2012) 71-75.

[22] S.G. Kim, S.H. Lee, N.H. Park, H.L. Park, K.W. Min, S.I. Mho, T.W. Kim, Y.H. Hwang, $\mathrm{Mn}^{2+}$ site behaviors in $\mathrm{Cd}_{\mathrm{x}} \mathrm{Zn}_{1-\mathrm{x}} \mathrm{Ga}_{2} \mathrm{O}_{4}$ and $\mathrm{Sr}_{\mathrm{x}} \mathrm{Ba}_{1-\mathrm{x}} \mathrm{Al}_{12} \mathrm{O}_{19}$ green phosphors, Solid State Commun., 110 (1999) 515-518.

[23] V. Singh, R.P.S. Chakradhar, J.L. Rao, H.-Y. Kwak, Investigations on green-emitting, $\mathrm{Mn}^{2+}: \mathrm{BaAl}_{12} \mathrm{O}_{19}$ phosphors obtained by solution combustion process, J. Mater. Sci., 46 (2011) 3928-3934.

[24] G.V.M. Williams, S. Schweizer, B. Henke, C. Dunford, A. Edgar, X-ray and UV induced photo-luminescence from $\mathrm{RbCdF}_{3}: \mathrm{Mn}^{2+}$, Curr. Appl. Phys., 6 (2006) 351-354.

[25] X. Zhang, H. Zeng, Q. Su, $\mathrm{Mn}^{2+}$-doped $\mathrm{Ba}_{2} \mathrm{ZnS}_{3}$ phosphor as a potential luminescent material for white LEDs, J. Alloys Compd., 441 (2007) 259-262.

[26] Y. Hao, Y. Wang, Luminescent properties of $\mathrm{Zn}_{2} \mathrm{SiO}_{4}: \mathrm{Mn}^{2+}$ phosphor under UV, VUV and CR excitation, J. Lumines., 122-123 (2007) 1006-1008.

[27] X.-J. Wang, D. Jia, W.M. Yen, $\mathrm{Mn}^{2+}$ activated green, yellow, and red long persistent phosphors, J. Lumines., 102-103 (2003) 34-37.

[28] J.A. Hernández, E.G. Camarillo, G. Muñoz, C.J. Flores, E.B. Cabrera, F. Jaque, J.J.

Romero, J. García Solé, H.S. Murrieta, Red and green fluorescence of $\mathrm{Mn}^{2+}$ in $\mathrm{NaCl}$, Opt. Mater., 17 (2001) 491-495.

[29] G. Härkönen, M. Leppänen, E. Soininen, R. Törnqvist, J. Viljanen, Multicolour thin film electroluminescent displays: a new application of rare earth metals, J. Alloys Compd., 225 (1995) 552-554.

[30] K. Kang, S.H. Huang, X.W. Huang, W.D. Zhuang, F.T. You, S.S. Zhang, H.Q. He, Preparation for a new green-emitting phosphor for cold cathode fluorescent lamp, J. Lumines., 122-123 (2007) 804-807.

[31] Y.-Y. Wang, T. Li, Y.-X. Qi, R.-L. Bai, L.-W. Yin, H. Li, N. Lun, Y.-J. Bai, Carboncoated manganese silicate exhibiting excellent rate performance and high-rate cycling stability for lithium-ion storage, Electrochim. Acta, 186 (2015) 572-578.

[32] A. Abragam, B. Bleaney, Electron paramagnetic resonance of transition ions, Oxford University Press, Oxford, 1970.

[33] J.W. Orton, Electron paramagnetic resonance, Gordon \& Breach Sc. Publ. Inc, New York, 1969.

[34] J.R. Pilbrow, Transition ion electron paramagnetic resonance, Clarendon Press, Oxford, 1990.

[35] D. Möncke, E.I. Kamitsos, A. Herrmann, D. Ehrt, M. Friedrich, Bonding and ion-ion interactions of $\mathrm{Mn}^{2+}$ ions in fluoride-phosphate and boro-silicate glasses probed by EPR and fluorescence spectroscopy, J. Non-Cryst. Solids, 357 (2011) 2542-2551.

[36] A.V.R. Kumar, C.S. Rao, N.N. Rao, V.R. Kumar, I.V. Kityk, N. Veeraiah, Influence of valence and coordination of manganese ions on spectral and dielectric features of $\mathrm{Na}_{2} \mathrm{SO}_{4}$ $\mathrm{B}_{2} \mathrm{O}_{3}-\mathrm{P}_{2} \mathrm{O}_{5}$ glasses, J. Non-Cryst. Solids, 358 (2012) 1278-1286.

[37] A. Moguš-Milanković, L. Pavić, K. Srilatha, C. Srinivasa Rao, T. Srikumar, Y. Gandhi, N. Veeraiah, Electrical, dielectric and spectroscopic studies on $\mathrm{MnO}$ doped $\mathrm{LiI}-\mathrm{AgI}-\mathrm{B}_{2} \mathrm{O}_{3}$ glasses, J. Appl. Phys., 111 (2012) 013714.

[38] R. Ganesan, B. Viswanathan, Redox properties of bis(8-hydroxyquinoline)manganese(II) encapsulated in various zeolites, J. Mol. Catal. A-Chem., 223 (2004) 21-29.

[39] D.E. De Vos, B.M. Weckhuysen, T. Bein, ESR fine structure of manganese ions in zeolite A detects strong variations of the coordination environment, J. Am. Chem. Soc., 118 (1996) 9615-9622.

[40] T.H. Bennur, D. Srinivas, P. Ratnasamy, EPR spectroscopy of copper and manganese complexes encapsulated in zeolites, Microporous Mesoporous Mat., 48 (2001) 111-118. [41] V.G. Makhankova, A.O. Beznischenko, V.N. Kokozay, R.I. Zubatyuk, O.V. Shishkin, J. Jezierska, A. Ozarowski, Direct synthesis, crystal structures, high-field EPR, and magnetic 
studies of heterometallic polymers containing manganese(II) carboxylates interconnected by $\left[\mathrm{Cu}(\mathrm{en})_{2}\right]^{2+}$, Inorg. Chem., 47 (2008) 4554-4563.

[42] PeakFit, Systat Software, Inc., www.systat.com/products/PeakFit/.

[43] S. Stoll, A. Schweiger, EasySpin, a comprehensive software package for spectral simulation and analysis in EPR, J. Magn. Reson., 178 (2006) 42-55.

[44] K.H. Stern, High temperature properties and thermal decomposition of inorganic salts with oxyanions, CRC Press, London, 2000.

[45] J. Hetmańczyk, Ł. Hetmańczyk, A. Migdał-Mikuli, E. Mikuli, Thermal properties of polycrystalline $\left[\mathrm{Mn}\left(\mathrm{NH}_{3}\right)_{6}\right]\left(\mathrm{ClO}_{4}\right)_{2}$, J. Therm. Anal. Calorim., 118 (2014) 1049-1056.

[46] T.F. Scientific, Manganese(II) perchlorate hexahydrate, Cat No. AC316510000 [Online], Fair Lawn, New Jersey, USA, 2015.

[47] L.D. Carlos, V. de Zea Bermudez, R.A. Sá Ferreira, L. Marques, M. Assunção, Sol-gel derived urea cross-linked organically modified silicates. 2. Blue-light emission, Chem. Mat., 11 (1999) 581-588.

[48] C. Fernández-Sánchez, C.J. McNeil, K. Rawson, Electrochemical impedance spectroscopy studies of polymer degradation: application to biosensor development, Trac-Trends Anal. Chem., 24 (2005) 37-48.

[49] M.A. Ratner, D.F. Shriver, Ion transport in solvent-free polymers, Chem. Rev., 88 (1988) $109-124$.

[50] S.C. Nunes, V.D. Bermudez, M.M. Silva, M.J. Smith, D. Ostrovskii, R.A.S. Ferreira, L.D. Carlos, J. Rocha, A. Goncalves, E. Fortunato, Sol-gel-derived potassium-based di-ureasils for "smart windows", J. Mater. Chem., 17 (2007) 4239-4248.

[51] R.D. Alves, L.C. Rodrigues, J.R. Andrade, M. Fernandes, J.V. Pinto, L. Pereira, A. Pawlicka, R. Martins, E. Fortunato, V. de Zea Bermudez, M.M. Silva, Gelatin $\mathrm{Zn}\left(\mathrm{CF}_{3} \mathrm{SO}_{3}\right)_{2}$ polymer electrolytes for electrochromic devices, Electroanalysis, 25 (2013) 1483-1490.

[52] L.C. Rodrigues, M.M. Silva, M.J. Smith, A. Gonçalves, E. Fortunato, Poly ( $\varepsilon-$ caprolactone)/siloxane biohybrids with application in "smart windows", Synth. Met., 161 (2012) 2682-2687.

[53] R. Leones, J.P. Donoso, C.J. Magon, I.D.A. Silva, A.S.S. de Camargo, A. Pawlicka, M.M. Silva, Ionic, paramagnetic and photophysical properties of a new biohybrid material incorporating copper perchlorate, Electrochim. Acta, 173 (2015) 76-81.

[54] C.B. Ferreira, M. Fernandes, L.C. Rodrigues, M.M. Silva, M.J. Smith, V. de Zea

Bermudez, Vibrational analysis of d-PCL(530)/siloxane-based hybrid electrolytes doped with two lithium salts, Ionics, 19 (2013) 1803-1809.

[55] Y. He, Y. Inoue, Novel FTIR method for determining the crystallinity of poly( $\varepsilon$ caprolactone), Polym. Int., 49 (2000) 623-626.

[56] A. Sanchis, M.G. Prolongo, C. Salom, R.M. Masegosa, Melting behavior, miscibility, and hydrogen-bonded interactions of poly(e-caprolactone)/poly(4-hydroxystyrene-co-

methoxystyrene) blends, J. Polym. Sci. Pt. B-Polym. Phys., 36 (1998) 95-104.

[57] V. de Zea Bermudez, D. Ostrovskii, M.C. Goncalves, L.D. Carlos, R.A. Sa Ferreira, L.

Reis, P. Jacobsson, Urethane cross-linked poly(oxyethylene)/siliceous nanohybrids doped with $\mathrm{Eu}^{3+}$ ions Part 1. Coordinating ability of the host matrix, Phys. Chem. Chem. Phys., 6 (2004) 638-648.

[58] S.C. Nunes, V. de Zea Bermudez, D. Ostrovskii, P.B. Tavares, P.C. Barbosa, M.M. Silva, M.J. Smith, Spectroscopic and structural studies of di-ureasils doped with lithium perchlorate, Electrochim. Acta, 53 (2007) 1466-1475.

[59] M. Chabanel, D. Legoff, K. Touaj, Aggregation of perchlorates in aprotic donor solvents. Part 1.-Lithium and sodium perchlorates, J. Chem. Soc.-Faraday Trans., 92 (1996) 4199-4205. [60] S.D. Ross, Forbidden transitions in the infra-red spectra of some tetrahedral anions - I. perchlorates, Spectroc. Acta, 18 (1962) 225-228.

[61] M.S. Reddy, G. Murali Krishna, N. Veeraiah, Spectroscopic and magnetic studies of manganese ions in $\mathrm{ZnO}-\mathrm{Sb}_{2} \mathrm{O}_{3}-\mathrm{B}_{2} \mathrm{O}_{3}$ glass system, J. Phys. Chem. Solids, 67 (2006) 789-795.

[62] P. Pascuta, M. Bosca, G. Borodi, E. Culea, Thermal, structural and magnetic properties of some zinc phosphate glasses doped with manganese ions, J. Alloys Compd., 509 (2011) 43144319. 
[63] V. Vamsi Priya, G. Upender, M. Prasad, FTIR and ESR studies of $\mathrm{VO}^{2+}$ and $\mathrm{Mn}^{2+}$ doped glasses of system $59 \mathrm{~B}_{2} \mathrm{O}_{3}-10 \mathrm{As}_{2} \mathrm{O}_{3}-(30-\mathrm{x}) \mathrm{PbO}-\mathrm{xBaO}$, Glass Phys. Chem., 40 (2014) 144-150. [64] R. Kripal, M. Maurya, Characterization of $\mathrm{Mn}^{2+}$ doped

tetramethylammoniumtetrachlorozincate single crystal using EPR and optical absorption, Mater. Chem. Phys., 108 (2008) 257-262.

[65] H.W. de Wijn, R.F. van Balderen, Electron spin resonance of manganese in borate glasses, J. Chem. Phys., 46 (1967) 1381-1387.

[66] V. Černý, B. Petrová, M. Frumar, EPR spectra of $\mathrm{Mn}^{2+}$ doped $\mathrm{CdX}_{2}-\mathrm{PbY}_{2}-\mathrm{KI}(\mathrm{X}, \mathrm{Y}=\mathrm{Cl}$, Br) glasses, J. Non-Cryst. Solids, 125 (1990) 17-24.

[67] A. Ciechanowska, J. Hanuza, E. Stanisławska, E. Kociołek-Balawejder, Synthesis of polymer-based hybrid materials via $\mathrm{Mn}(\mathrm{II})$ oxidation with N-bromosulphonamide polymer and their characterization, J. Mater. Sci., 50 (2015) 4300-4311.

[68] P.A. Gonzalez Beermann, B.R. McGarvey, S. Muralidharan, R.C.W. Sung, EPR spectra of $\mathrm{Mn}^{2+}$-doped ZnS quantum dots, Chem. Mat., 16 (2004) 915-918.

[69] J.S. van Wieringen, Paramagnetic resonance of divalent manganese incorporated in various lattices, Discuss. Faraday Soc., 19 (1955) 118-126.

[70] E. Šimánek, K.A. Müller, Covalency and hyperfine structure constant A of iron group impurities in crystals, J. Phys. Chem. Solids, 31 (1970) 1027-1040.

[71] R.W.A. Franco, J.F. Lima, C.J. Magon, J.P. Donoso, Y. Messaddeq, Magnetic resonance study of the crystallization behavior of $\mathrm{InF}_{3}$-based glasses doped with $\mathrm{Cu}^{2+}, \mathrm{Mn}^{2+}$ and $\mathrm{Gd}^{3+}, \mathrm{J}$. Non-Cryst. Solids, 352 (2006) 3414-3422. 


\section{Figures}

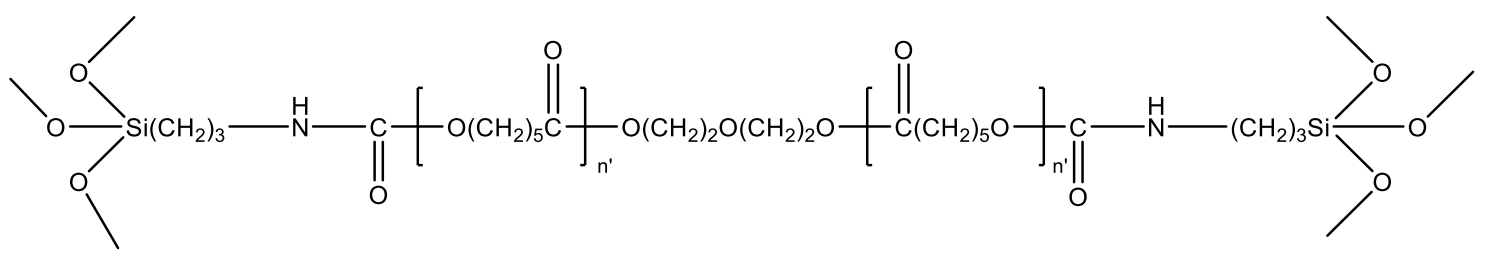

Fig. 1. Structure of the d-PCL(530)/siloxane hybrid host matrix with $2 n^{\prime}=3.7$.

Fig. 2. Appearance of a representative d-PCL(530)/siloxane ${ }_{n} \mathrm{Mn}\left(\mathrm{ClO}_{4}\right)_{2}$ biohybrid. 


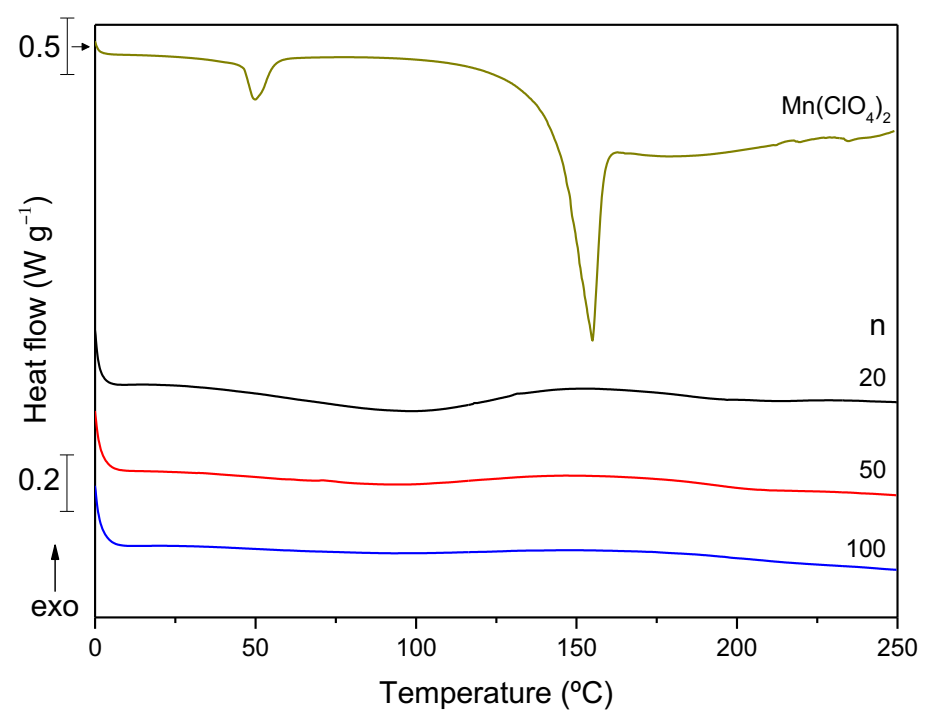

Fig. 3. DSC thermograms of,d-PLC $(530) /$ siloxane $_{n} \mathrm{Mn}\left(\mathrm{ClO}_{4}\right)_{2}$ biohybrids and $\mathrm{Mn}\left(\mathrm{ClO}_{4}\right)_{2}$ salt.

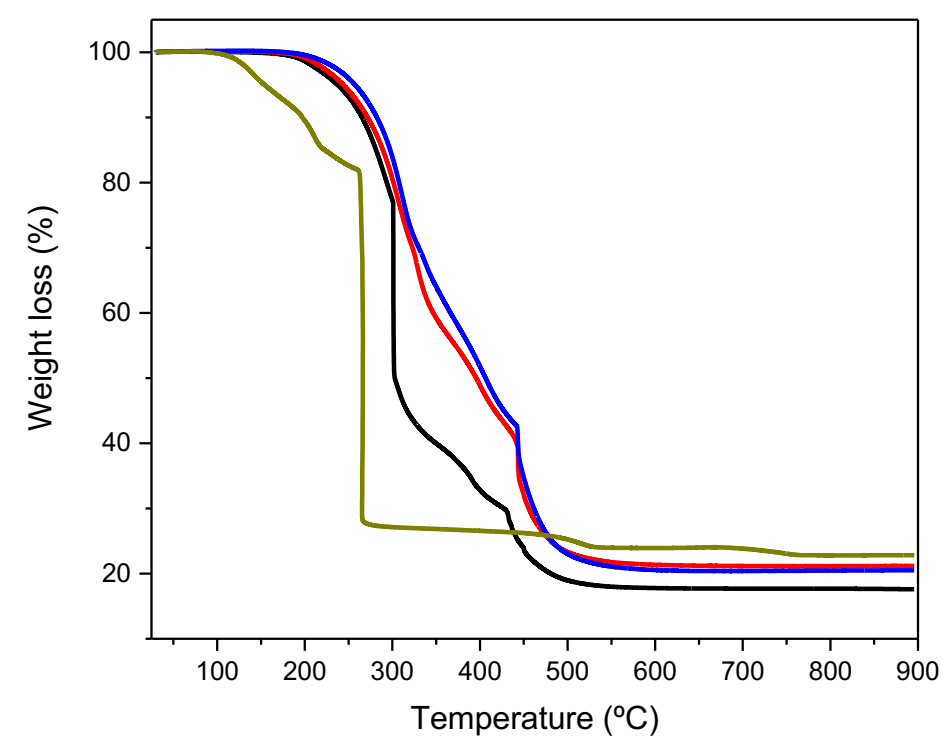

Fig. 4. TGA curves of the d-PLC(530)/siloxane ${ }_{n} \mathrm{Mn}\left(\mathrm{ClO}_{4}\right)_{2}$ biohybrids with $\mathrm{n}=100$ (blue line), $\mathrm{n}=50$ (red line), $\mathrm{n}=20$ (black line) and $\mathrm{n}=0$ (dark yellow). 

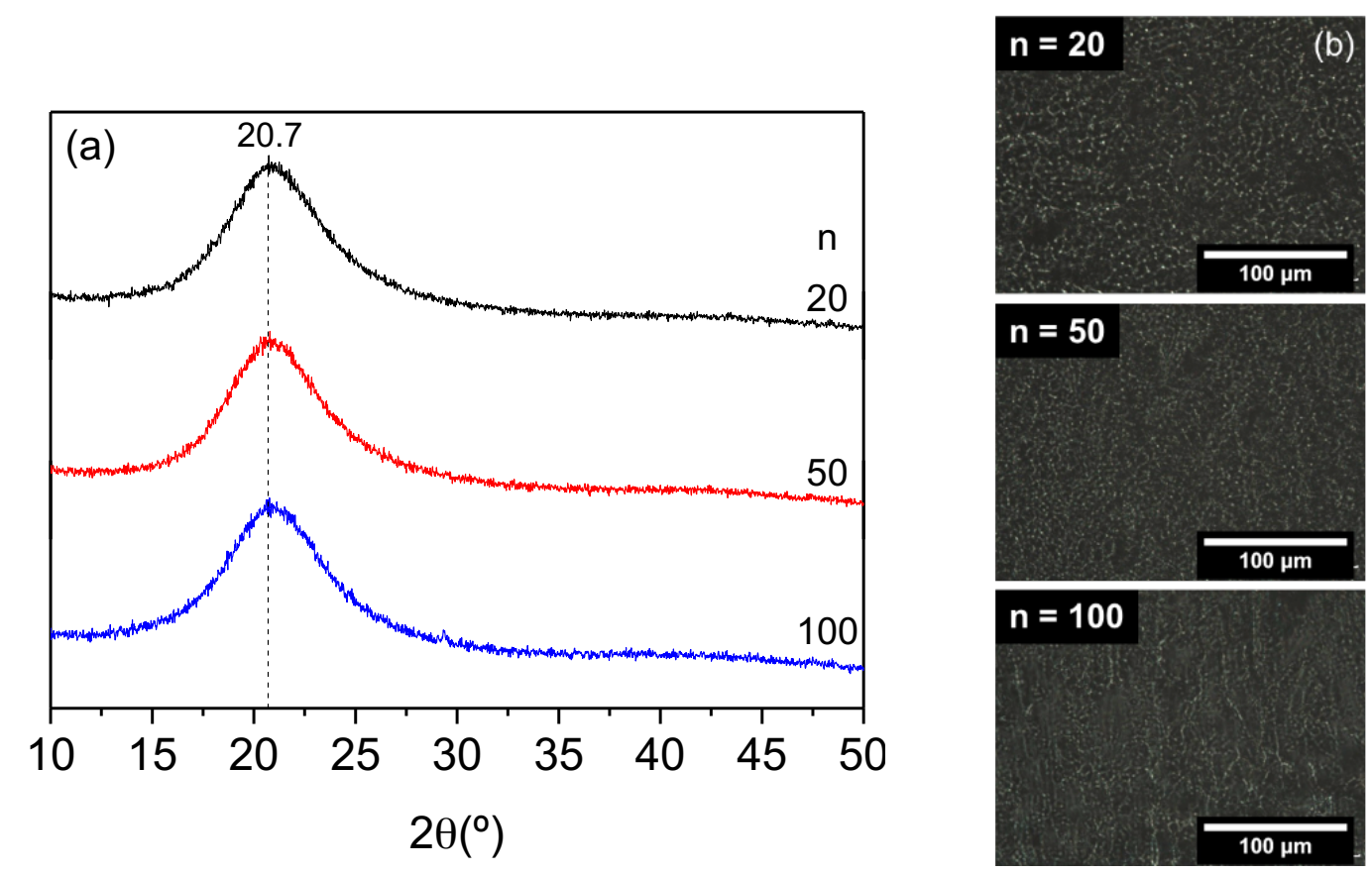

Fig. 5. (a) XRD patterns and (b) POM images of d-PLC(530)/siloxane ${ }_{n} \mathrm{Mn}\left(\mathrm{ClO}_{4}\right)_{2}$ biohybrids with $n=100$ (blue line), $n=50$ (red line) and $n=20$ (black line).
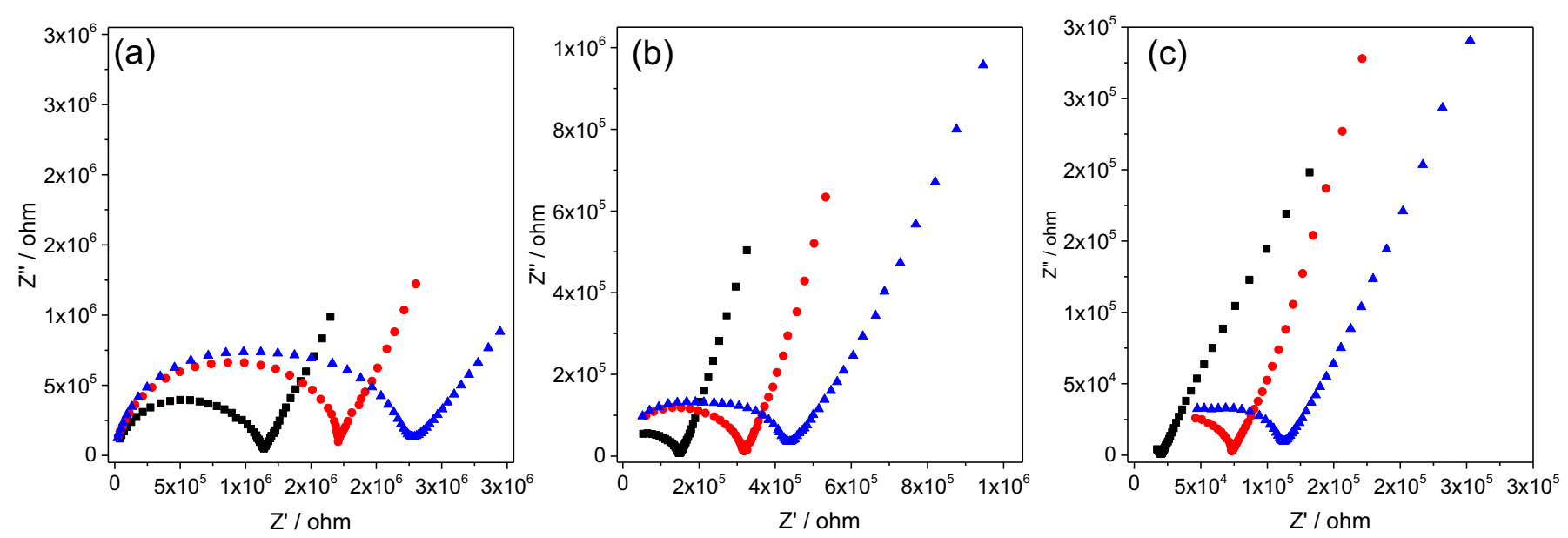

Fig. 6. Nyquist plots of the d-PCL(530)/siloxane ${ }_{n} \mathrm{Mn}\left(\mathrm{ClO}_{4}\right)_{2}$ biohybrids with $\mathrm{n}=100$ (blue symbols),, $\mathrm{n}=50$ (red symbols) and $\mathrm{n}=20$ (black symbols), at $25^{\circ} \mathrm{C}$ (a), $50{ }^{\circ} \mathrm{C}$ (b), and $105^{\circ} \mathrm{C}(\mathrm{c})$. 


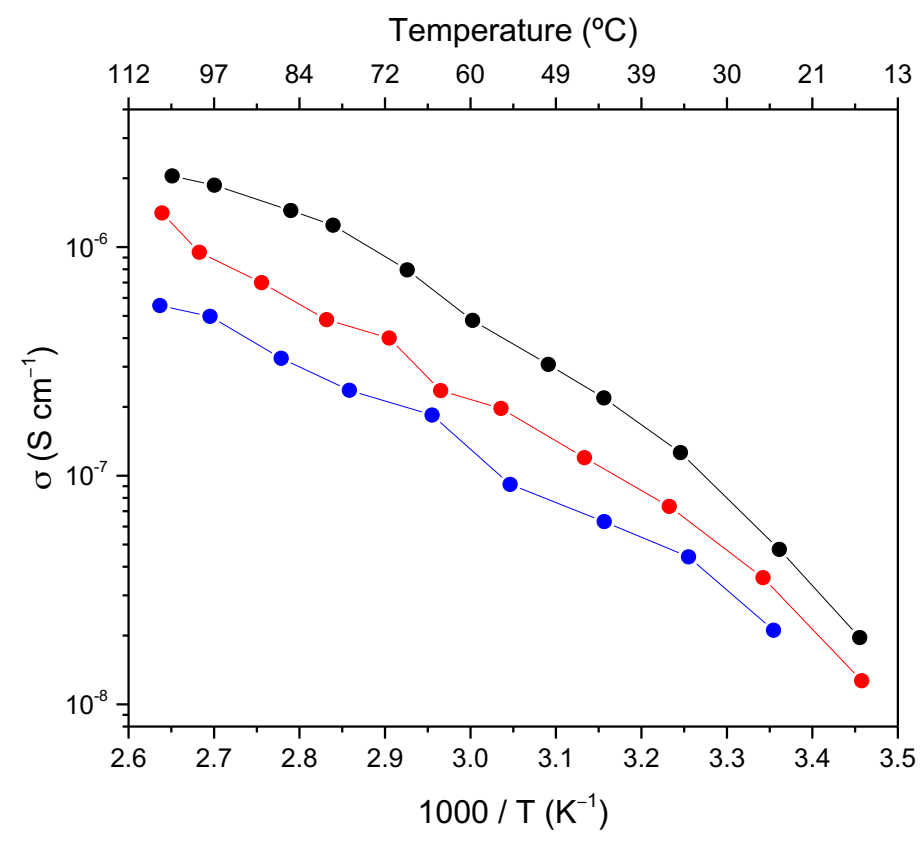

Fig. 7. Conductivity plot of the d-PCL(530)/ siloxane ${ }_{n} \mathrm{Mn}\left(\mathrm{ClO}_{4}\right)_{2}$ biohybrids for $\mathrm{n}=100$ (blue symbols), $\mathrm{n}=50$ (red symbols) and $\mathrm{n}=20$ (black symbols). The lines are just guides for the eyes. 

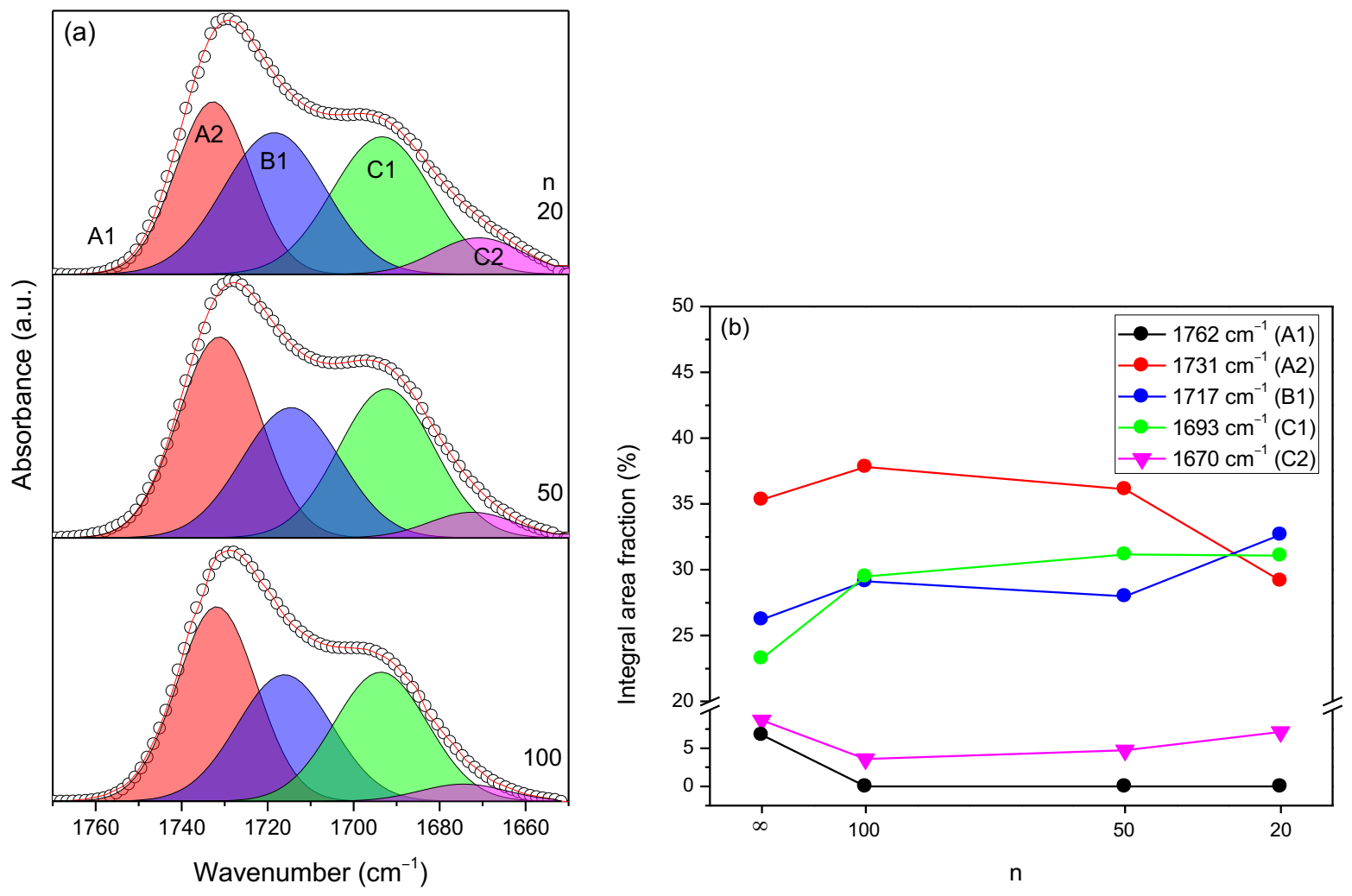

Fig. 8. (a) Results of the curve-fitting performed in the "amide I" region and (b) salt concentration dependence of the integral fraction of the resolved "amide I" bands (data for $\mathrm{n}=\infty$ have been reproduced from [8]) of the d-PLC(530)/siloxane ${ }_{n} \mathrm{Mn}\left(\mathrm{ClO}_{4}\right)_{2}$ biohybrids. 

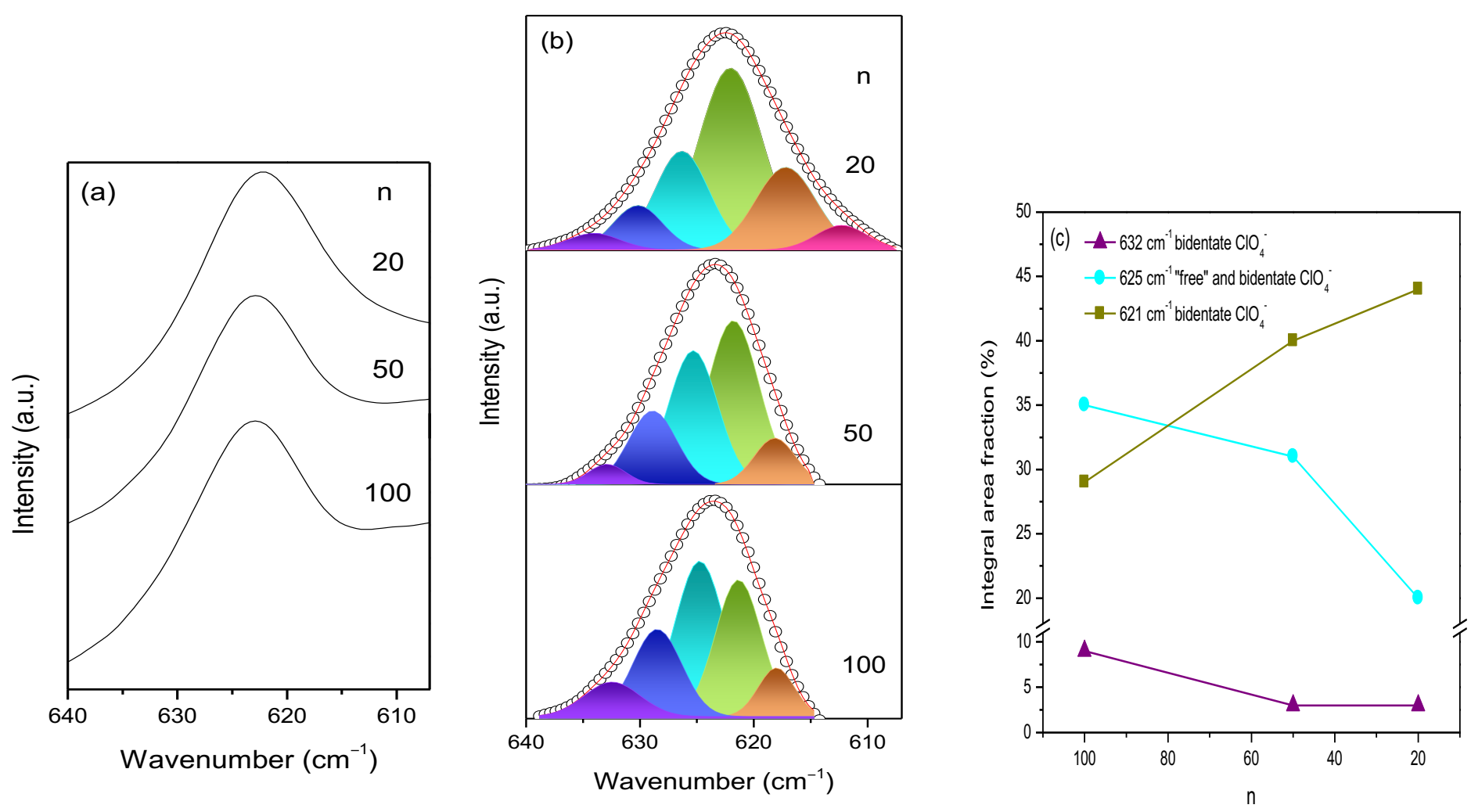

Fig. 9. (a) FT-IR spectra of the d-PLC(530)/siloxane ${ }_{n} \mathrm{Mn}\left(\mathrm{ClO}_{4}\right)_{2}$ biohybrids in the FTIR $v_{4} \mathrm{ClO}_{4}$ region; (b) Results of the curve-fitting; (c) Salt concentration dependence of the integral area fraction of selected $v_{4} \mathrm{ClO}_{4}$ components (the lines drawn are just guides for the eyes). 

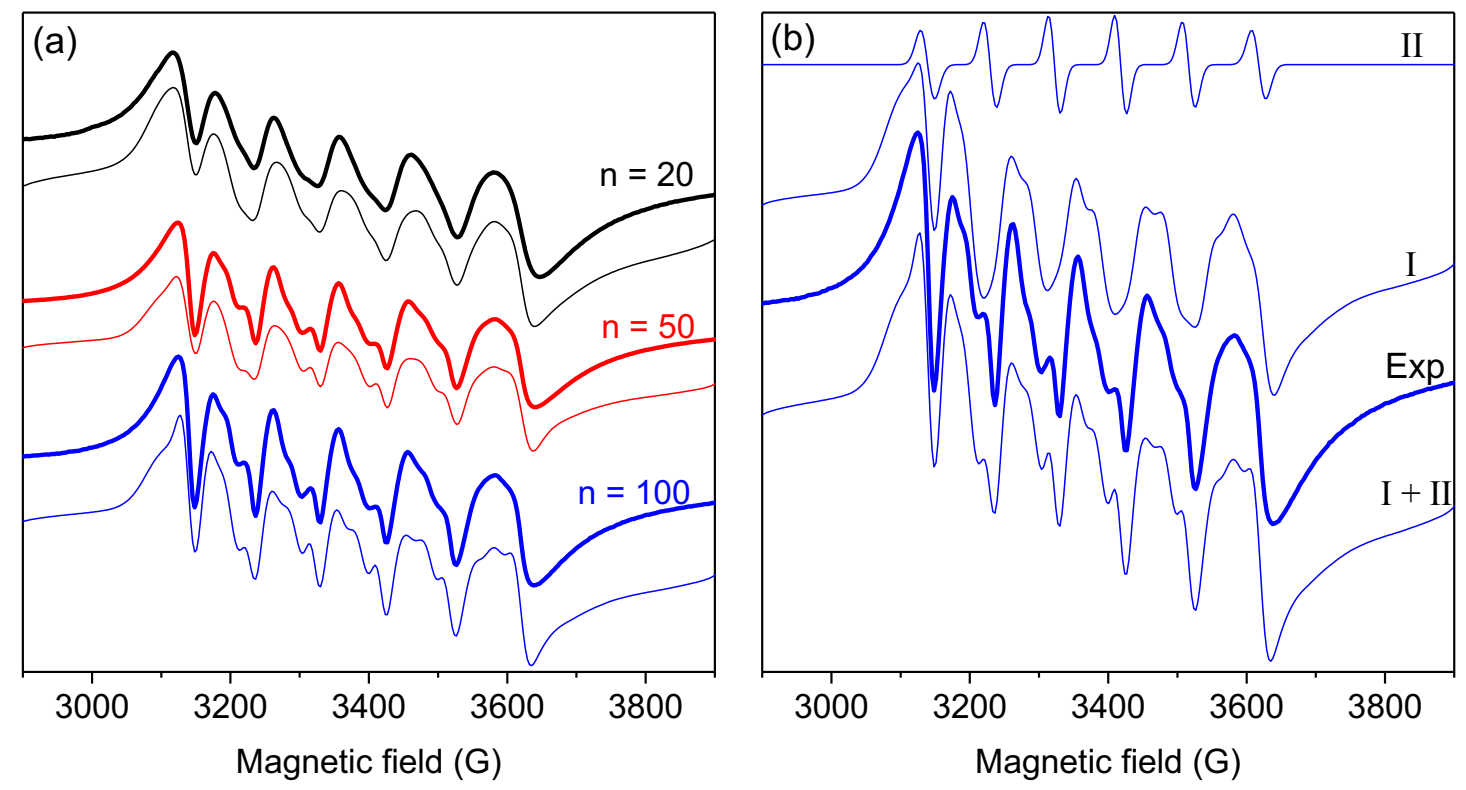

Fig. 10. (a) Experimental (bold lines) and simulated (normal lines) EPR spectra of d$\operatorname{PLC}(530) /$ siloxane $_{n} \mathrm{Mn}\left(\mathrm{ClO}_{4}\right)_{2}$ biohybrids $(\mathrm{n}=20,50$, and 100), recorded at $50 \mathrm{~K}$. (b) Experimental (thick line) and numerical simulation (thin lines) of the $\mathrm{Mn}^{2+} \mathrm{EPR}$ signal for $n=100$ : considering species II, species I and full simulated spectrum (I + II). 